\title{
Observations on the Fal Estuary Oyster Beds during 1926, including a study in Over-fishing.
}

\author{
By
}

J. H. Orton, D.Sc.,

Chief Naturalist at the Plymouth Laboratory.

With 3 Figures in the Text.

\section{CONTENTS.}

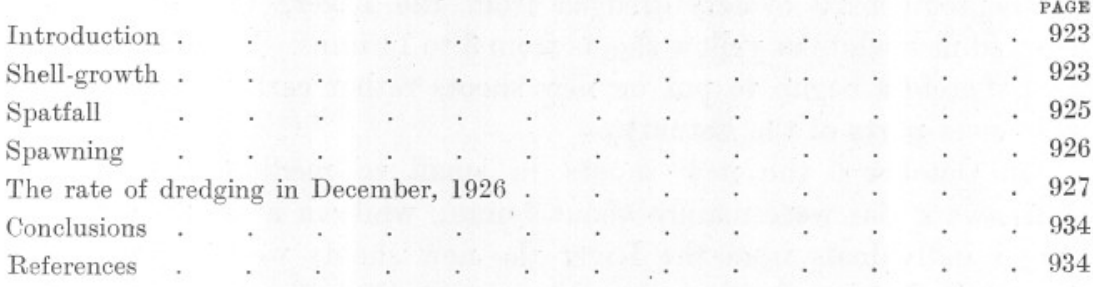

\section{INTRODUCTION.}

DURING the summer and autumn of 1926 frequent visits were made to the oyster beds in the upper Fal Estuary, and in view of the continued decline in the yield of oysters from these grounds, the opportunity was taken to record any facts which, besides being of value in the study of the bionomics of the oyster, might also be helpful in determining those steps most likely to lead towards an improvement of the general state of the fishery. A special investigation of the spawning in relation to tides and temperature was made, and will be compared in a separate publication with similar work carried out at about the same time on the River Blackwater beds in Essex.

\section{SHELL-GROWTH.}

A few general observations on shell-growth may be noted. In a sample of oysters dredged from Turnaware Bar and examined the following day, April 22, of 73 individuals with normal shells, 53 had already begun to deposit shell-material and had new shoots of 1 to $9 \mathrm{~mm}$. (measured in the median dorso-ventral line on the left valve). The shells were covered with slight growths of red and brown filamentous algæ. Shell-growth had therefore begun about the middle of April or earlier. 
In samples of oysters dredged from Turnaware Bar on May 26, large individuals (over $2 \frac{5}{8}$ inches long) with normally-grown shells had thin white new shoots up to $12 \mathrm{mms}$. and smaller ones had shoots up to 10 mms.; dumpy and slightly dumpy oysters in the same samples showed shoots up to $9 \mathrm{mms}$., but the proportion of individuals of these kinds with no shoots at all was relatively very high. Similar growth was observed on a sample from the south end of the East Edge on May 21. During June the new growth hardened, that is, thickened, but the shoots did not increase in extent. In the remainder of the summer no special attention was given to observing shell-growth, but it was remarked that no new general outburst of growth occurred until the autumn. On September 21 new small thin shoots of shell appeared on oysters taken on the shore at Turnaware Bar, and a small proportion of shells dredged in the same locality on the 24th showed also slight new growth; but on September 29 oysters dredged from the River, Trelissick Reach, showed new white or yellow shoots from 3 to $14 \mathrm{mms}$. The River oysters had therefore begun to put on new shoots rather earlier than those in the lower parts of the Estuary.

On October 6 the new shoots in small to medium oysters from Turnaware Bar were mainly about $7 \mathrm{~mm}$., while in a sample of rather larger individuals from the River the new shoots were mainly about $10 \mathrm{mms}$. During October new shoots up to $10 \mathrm{mms}$. Were found in a high proportion of individuals all over the grounds, but on working out an average shoot, this was found to be generally about 4 to $5 \mathrm{~mm}$. On all the grounds the shoots strengthened towards the end of the month, but there was much soft new shell even in November. On October 28 an important sample from the Falmouth North Bank showed new thin white growths, clearly more recent than that on beds higher in the Estuary and in strong contrast with the hardening shoots on the shells from the Truro beds. New depositions destined to form chambers were also frequently seen in October. On October 28 and 29 samples were examined from the Channel (off the Poles Rocks), Mylor and East Banks, and it was found that whereas new growth had occurred in a high proportion in the shells from the two latter beds, little had occurred in the Channel oysters, in which shoots of only 2 to $3 \mathrm{~mm}$. of indecisive growth were found.

Thus in 1926 shell-growth began in April, or possibly a little earlier, on some parts of the beds and continued generally over the beds in May and June. During the summer this spring growth thickened, but no new general growth occurred during the summer. Towards the end of September a new general outburst of shell-growth occurred, beginning in the upper parts of the beds and extending to the lower parts in October. During October and early November this autumn growth was hardening, 
and the last new growth was seen on the Falmouth North Bank on October 28, and had probably taken place about the middle of the month.

These observations are of great importance from the point of view of oyster-cultivation. Oysters dredged in October had soft new shoots which were easily broken, and it is well known that oysters with broken shells are unfit to withstand successfully the hardships of transportation for relaying. In addition the oysters were mostly poorly fished, that is, had small reserves of food-material in the early part of October, but many rapidly improved at the end of the month and in November.

\section{Spatfall.}

During the examination of different parts of the beds, it was possible to obtain a good general idea of the spatfall in the different parts of the ground. The spatfall in the river, in 1925 and 1926, especially at Trelissick Reach, on the east side, was fairly good, and was apparently equally good in higher parts. On the Edges everywhere spat had settled in fair amounts, and there was also a fair fall on Turnaware Bar. On the Banks the fall was slight, but spat or young brood could generally be seen in a dredge-haul from these beds. The total fall of spat is, however, very small compared with the total amount of oysters taken from the beds. In view of the fact that the summers in 1925 and 1926 were highly favourable for spatfall, in so far as the important factor of weather is concerned, the discrepancy between the input of oysters, as measured by the spatfall, and the outtake, as measured by the dredging-catches, is serious. The outtake of oysters may be measured by the catches of large oysters recorded in Tables I and II (pages 928 and 929), and the input by the catches of brood and spat in the same hauls.

The conclusion to be drawn from the observations on spatfall is that the resources of the authorities should be concentrated on the Banks and Turnaware Bar. These beds would take easily and with profit more than 100 tons of shell-cultch. The cultch on the edges of the Banks, the Channel, and the River is kept sufficiently clean and is present in sufficient amount to give attachment to a relatively great amount of oyster larvæ; these parts of the beds therefore do not need cultivating at present for the capture of spat. As the number of adult spawning oysters on the grounds is decreasing, there is a decrease in the potential number of oyster larvæ, and a corresponding decrease in the expectation of number of spat which will settle on cultch. Therefore, in spite of the promising fall of spat in parts of the River, the spatfall as a whole is inadequate to make up the present loss on the beds. 


\section{SPAWNING.}

During May, 1926, and up to June 9, about a thousand oysters were examined mostly from Turnaware Bar and only five oysters found in spawn, of which four were probably forced or premature spawners. From June 15 to June 23 an additional thousand oysters from the same beds yielded only four more spawning oysters, which were also in all probability premature spawners. On'the spring tides at about full moon at the end of June, however, regular spawning began and continued throughout the summer until the full moon spring tides about September 23 . On Turnaware Bar a high proportion of individuals could be found, in parts of the beds, carrying larvæ after the dredging season opened. For example, on October 4 out of 108 oysters examined 10 were blacksick, and on October 5 in the same place 13 were found blacksick out of 119 examined. This was the end of the spawning in 1926.

The spawning season in 1926 therefore extended from the end of June to the third week in September, but there is evidence that the spawning season varies slightly in extent on different parts of the Fal Estuary beds, beginning and ending early on the upper parts and on the exposed foreshores, as at Turnaware Bar, and beginning and ending rather later in the lower parts of the beds and in the lower parts of the Channel. A full discussion of the information obtained will be given later. The fact that the spawning season in the upper Fal Estuary beds - excluding the higher reaches of the River where no observations could be made- did not begin until the end of June is one of great interest. On the West Mersea oyster beds (Blackwater River, Essex) spawning was well advanced on June 16, as is shown by the fact that a sample of 104 oysters examined on that date contained 7 blacksick and 7 whitesick oysters, while of 1000 examined at the Fal Estuary between June 15 and 23 only 4 were whitesick, which were also in all probability premature spawners. This difference in the time of beginning of a general spawning on the east and west coast beds compared is probably usual, and can be correlated with the different temperature conditions in the two localities. On the east coast beds the temperature of the sea-water rises and falls rapidly directly with variations in duration of sunshine and air-temperature, whereas on the west coast beds the change is slower. The slowness of the change on the west coast beds is due to the large body of tidal water flowing into and out of the deep channels in the Fal Estuary beds (10 to 15 fathoms) directly from the English Channel, and this large body of water can only be warmed up slowly. On the east coast beds the shallower water warms up quickly, but in addition the configuration of the north-west portion of the Thames Estuary at the mouth of the River Blackwater is such"as to render there even a large body of tidal 
water more susceptible to temperature changes in the air than on the Fal Estuary beds. A complete discussion of the matter cannot, however, be given here.

The factor of the time at which regular spawning begins on any oyster bed is an important one in connexion with the size attained by spat in the first year of growth, but an equally important factor also is the extent of the period in which shell-growth occurs on the same beds in the same season. In 1926 spat may have settled on the Fal Estuary beds in fair numbers by the middle of July, and could have continued growth until about the middle of October, a period of about three months, but as the larvæ would continue to settle throughout the summer, the majority of the spat would have a shorter period of growth than three months.

\section{The Rate of Dredging in December, 1926.}

During the autumn of 1926, visits were paid to the Fal Estuary Oyster Beds for the purpose of obtaining temperature readings at different parts of the beds at different states of the tides. It was hoped to combine this work with observations on the rate of dredging in November to compare with that found in November, 1924, but the weather was so stormy in this month that this work had to be delayed until December; but as relatively little work was done on the beds in November, the results obtained are probably not very different from those which would have accrued if the work could have been carried out as planned.

Dredging was carried out on December $9,10,16$, and 17, from both rowing and sailing boats, and the whole of the oysters caught recorded and measured as described in the Report on a Survey of the Fal Estuary Oyster Beds, 1926, pp. 9-14. The results obtained during December, 1926, along with those recorded from November, 1924, will form a valuable basis for comparison of the state of the Fal Estuary oyster fisheries in the future.

The details of the dredging from sailing and rowing boats in December, 1926, are given in Tables I and II on pp. 928 and 929 respectively. These tables may be compared with the similar ones given in the report of the work in November, 1924, as follows: Table I herein gives information corresponding to that found in Tables II and III, pp. 29-31, of the November, 1924, survey, and Table II herein corresponds to Table IV, p. 31.

The essential facts obtained from a comparison of the dredging results in 1924 and 1926-shown graphically in Figs. 1 and 2, pp. 930 and 931 -are as follows :-

1. That whereas in 1924, 237 dredge-hauls-of average duration of $6 \cdot 2$ minutes-were made from sailing boats, in 1926, 387 similar 


\section{TABLE I.}

Results of Dredging from Sathing Boats on the Truro Grounds, Upper Fal Estuary, December 9-17, 1926, Showing the average Catch and time of Dredge-hauls and the numbers and percentages of DifFerent Categories of Oysters taken.

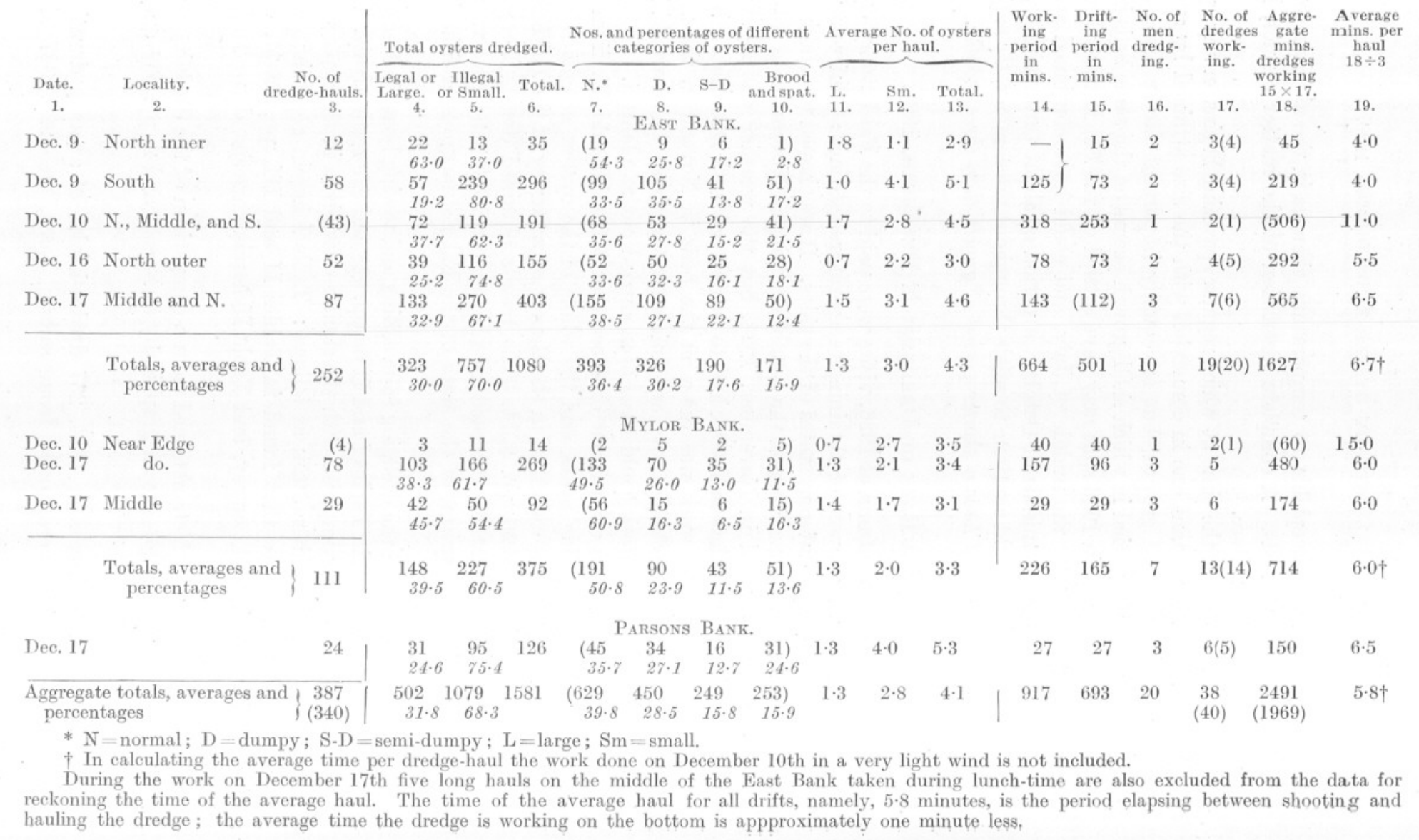


TABLE II.

Results of Dredging from Rowing Boats in the Upper Fal Estuary, December 9-17, 1926, showing the averagk time and CATCh of Dredge-hauls and numbers and percentages of Different Categories of Oysters taken.

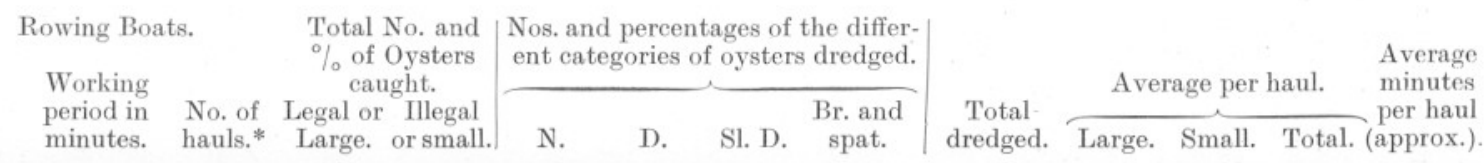

\begin{tabular}{llllll|llll|llll} 
(1) December 10 & 360 & 40 & 52 & 646 & 216 & 182 & 116 & 184 & 698 & $1 \cdot 3$ & $16 \cdot 1$ & $17 \cdot 4$ & $9 \cdot 0$ \\
& & & $7 \cdot 4$ & $92 \cdot 6$ & $30 \cdot 9$ & $26 \cdot 1$ & $16 \cdot 6$ & $16 \cdot 4$ & & & &
\end{tabular}

\begin{tabular}{llllll|cccc|cccc} 
(2) December 10 & 400 & 40 & 61 & 618 & 247 & 82 & 190 & 160 & 679 & $1 \cdot 5$ & $15 \cdot 4$ & $17 \cdot 0$ & $10 \cdot 0$ \\
& & & $9 \cdot 0$ & $91 \cdot 0$ & $36 \cdot 4$ & $12 \cdot 1$ & $2 \% \cdot 9$ & $23 \cdot 6$ & & &
\end{tabular}

Mylor Bank Edge.

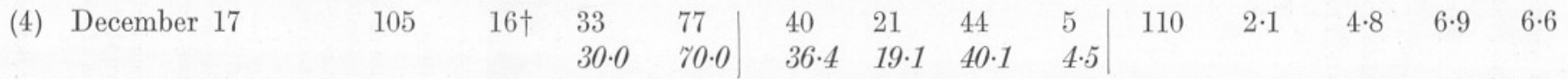

\begin{tabular}{llllll|lllll|llll} 
(7) & December 9 & 150 & 18 & 27 & 183 & 78 & 71 & 30 & 31 & 210 & 1.5 & $10 \cdot 0$ & $11 \cdot 5$ & $8 \cdot 3$
\end{tabular}

(13) December 10

Parsons Bank, Edge and Bank near Pill Creek.

Totals, averages and

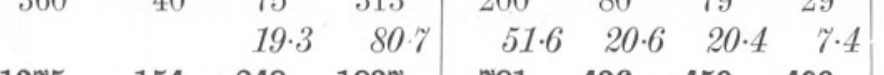
percentages

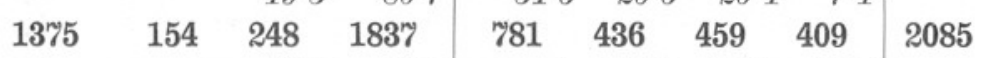

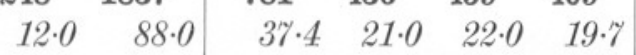

$\begin{array}{rrrr}1.9 & 7 \cdot 8 & 9 \cdot 7 & 9 \cdot 0 \\ \mathbf{1 . 6} & \mathbf{1 1 . 9} & \mathbf{1 3 . 5} & \mathbf{8 . 9}\end{array}$

* The number of rowing-boat hauls given is a close approximation and is not derived from actual records. $†$ Two small dredges used. 
dredge-hauls-of average duration of about 6 minutes-were made with the following different results :-

\author{
Average catches of Average daily catch per man \\ Large. oysters per haul. Total.
}

November, $1924 \quad 4 \cdot 2\left(2 \frac{1}{2}\right.$-inch ring) $\quad 6 \cdot 4 \quad 10 \cdot 6 \quad 300-325$

December, $1926 \quad 1 \cdot 3\left(2 \frac{5}{8}\right.$-inch ring) $\quad 2 \cdot 8 \quad 4 \cdot 1 \quad$ About ${ }^{5} 100$

FIG. 1 (1926)

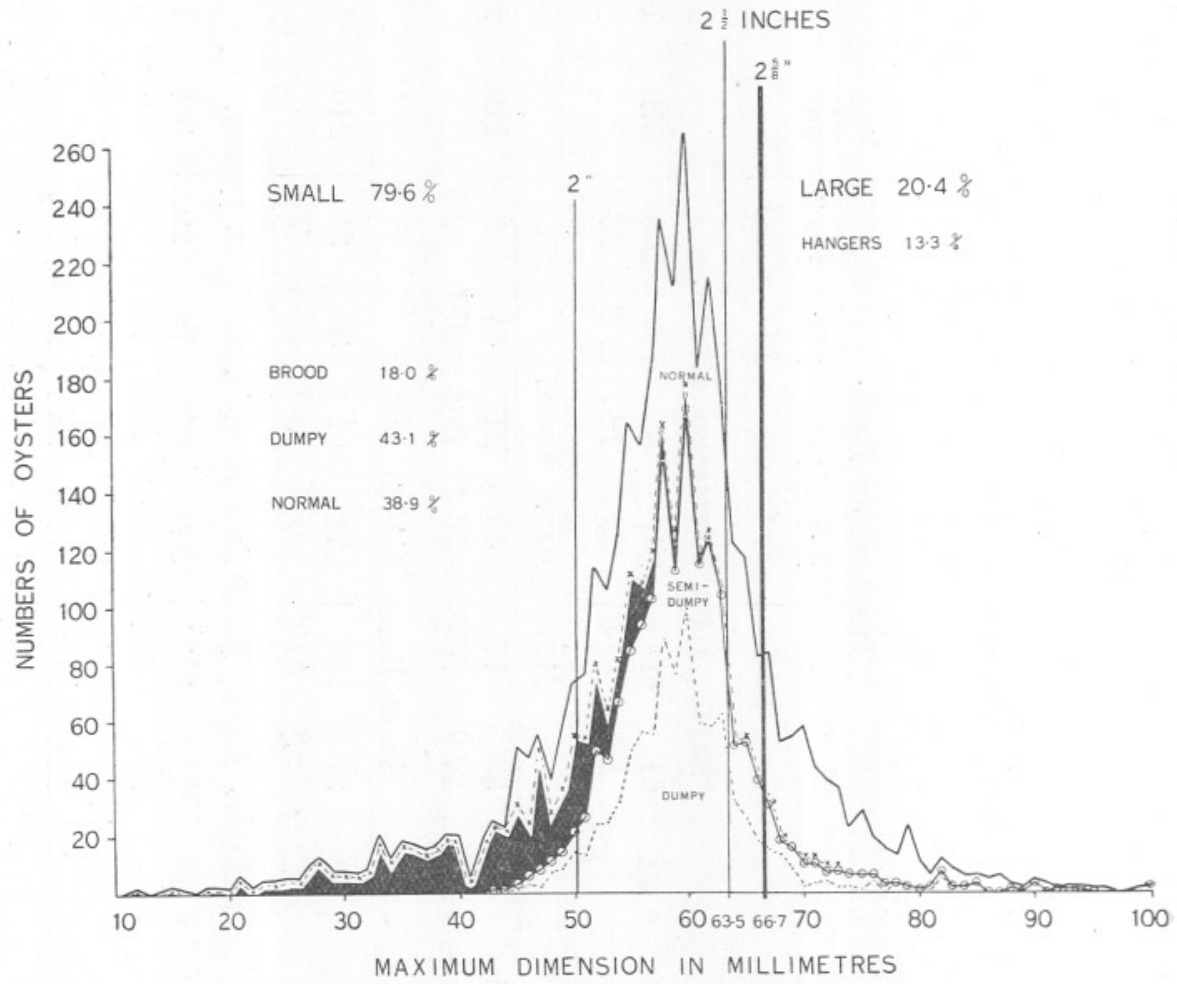

FIG. 1.*-Graph of the maximum shell-dimensions of 3,666 oysters dredged on the Truro beds, Upper Fal Estuary, December 9-17, 1926, in 387 hauls with sailing-boat dredges and about 154 hauls with rowing-boat dredges, showing the size-distribution and the proportions of the different categories of individuals constituting the population at the time.

The graph is built up by plotting successively the dumpy individuals (denoted by the thin broken line with dots), the semi-dumpy individuals (denoted by the thinner continuous line with circles), the brood and spat (denoted by the black area and broken line with crosses), and the normal, which give mostly the main outline of the graph.

The hangers observed constitute $2 \cdot 7 \%$ of the whole catch and $13 \cdot 3 \%$ of the large or legal oysters : it is known that the actual percentage was higher than these figures indicate, but the conditions of working prevented records being made in every case observed.

* I am indebted to Mr. J. H. Bowden for the drawings for this figure and for Fig. 3. 
2. That the rowing-boat catches made in 1926, when all the parts of the grounds richest in small oysters were well sampled, and those made in 1924 show the following differences:-

$$
\begin{array}{cc}
\begin{array}{c}
\text { Average catch of } \\
\text { oysters per haul. } \\
\text { Small. Total. }
\end{array} & \begin{array}{c}
\text { Average daily catch per } \\
\text { man of large oysters. }
\end{array} \\
\text { Sarge. } &
\end{array}
$$

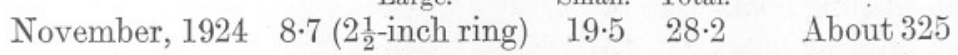

December, $1926 \quad 1 \cdot 6\left(2 \frac{5}{8}\right.$-inch ring) $\quad 11.9 \quad 13.5 \quad$ About 50-75 (100)*

3. The oysters on the grounds in 1926, when divided into those $(a)$

FIg. 2 (1924)

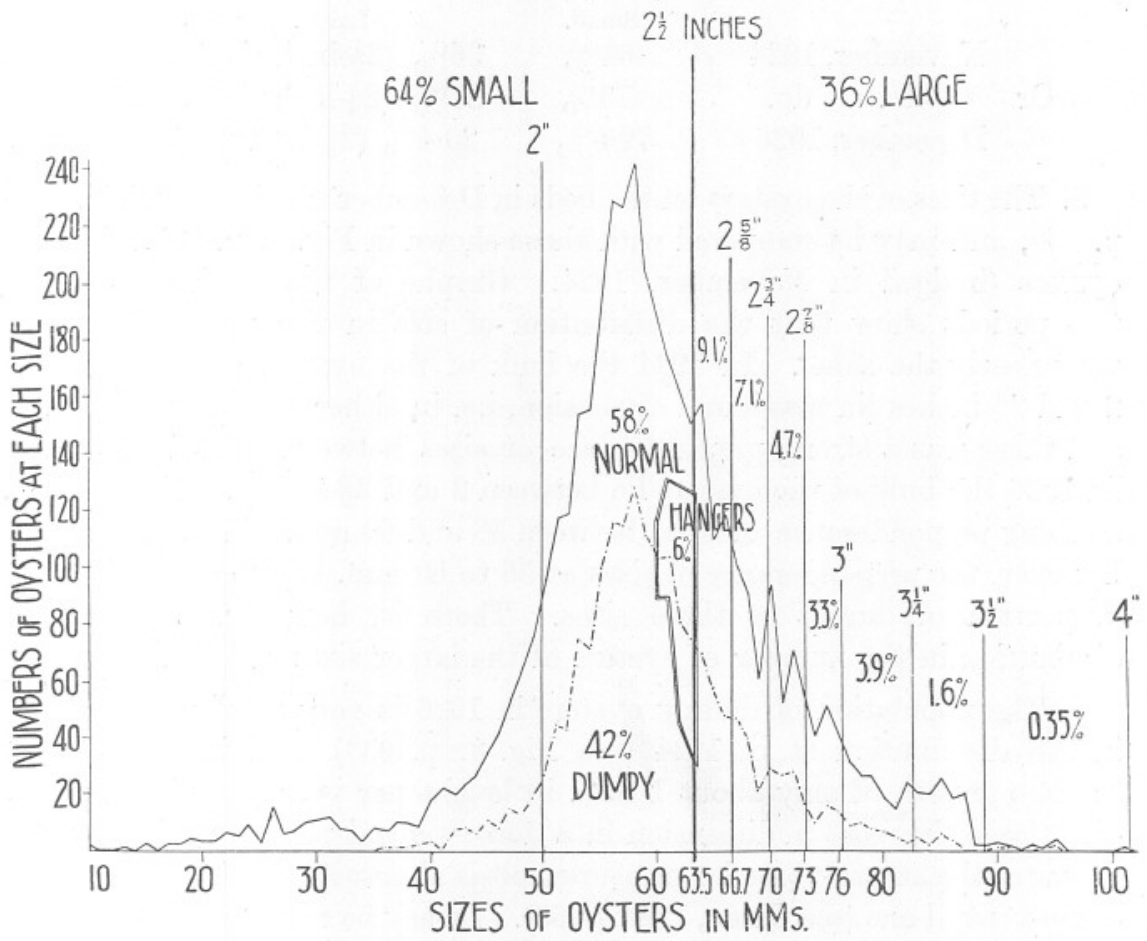

FIg. 2.†-Graph of the maximum shell-dimensions of 4,243 oysters dredged on the Truro beds, Upper Fal Estuary, November, 1924, in 270‡ hauls with sailing-boat dredges and 49 hauls with rowing-boat dredges, showing the composition in size of the stock, and the proportion of dumpy and normal oysters at different sizes.

* When the dredgerman is culling only for large oysters he can work at a quicker rate, but in the rowing-boat catches for December, 1926, one man had to eull both large and small. It is probable that at this time ordinary rowing-boat dredgermen were catching on the average from 75 to about 100 legal oysters per day.

+ Reproduced from the Report of the Survey in 1924 .

* In the Report referred to records are given of 237 dredge-hauls from sailing boats and 49 hauls from rowing boats, from the whole of which 3,897 of the oysters graphed above were obtained. In order to render the graph of these oysters more easily comparable with that of the sample taken in 1926, an additional 33 hauls from sailing-boat dredges (of average catch of $10 \cdot 6$ oysters) have been added to account for the whole total of 4,243 . 
with normally grown shells, $(b)$ with dumpy or semi-dumpy and slowgrowing shells, and $(c)$ very young oysters, namely, brood and spat of one to three summers' growth, showed the following proportions :-

\begin{tabular}{|c|c|c|c|}
\hline Frol & $\begin{array}{l}\text { Normal. } \\
40 \%\end{array}$ & $\begin{array}{c}\text { Dumpy and } \\
\text { semi-dumpy. } \\
44 \%\end{array}$ & $\begin{array}{c}\text { Brood and spat. } \\
15.9 \%\end{array}$ \\
\hline From rowing boats & $37 \cdot 4 \%$ & $43 \%$ & $19 \cdot 7 \%$ \\
\hline
\end{tabular}

In 1924 the proportion of dumpy and semi-dumpy oysters was $42 \%$.

4. The proportions of small and large oysters dredged in the two periods are :-

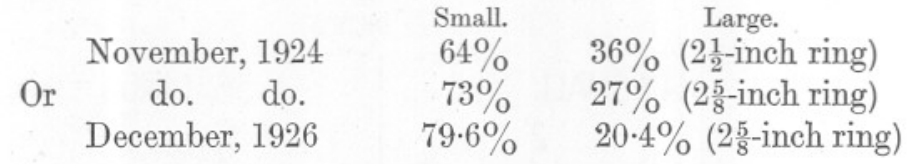

5. The sizes of the oysters on the beds in December are shown in Fig. 1, p. 930, and may be compared with those shown in Fig. 2, p. 931, of the oysters dredged in November, 1924. Graphs of the catches at the two periods show that the distribution of size in the populations is very nearly the same. In 1924 the bulk of the oysters were between 2 and $2 \frac{3}{4}$ inches (in maximum dimension, i.e. in either length or height), and there was a strong preponderance of sizes between 56 and $58 \mathrm{~mm}$. In 1926 the bulk of the oysters lie between 2 and $2 \frac{5}{8}$ inches, and there is a strong preponderance of sizes between 58 and $60 \mathrm{~mm}$. In both years, however, the preponderance of sizes at 56 to $60 \mathrm{~mm}$. is due to the large proportion of dumps at these sizes. There is, however, a distinct diminution in the number of oysters of the larger sizes in 1926 .

6. The population of dumpy oysters in 1926 is very nearly the same in size-distribution as in 1924 (see Fig. 3. p. 933), and indicates an average growth of only about $1 \mathrm{~mm}$. in height per year (that is, in the direction of increase in dimension in a dorso-ventral plane; in this type of oyster the antero-posterior measurement is almost always less than the dorso-ventral one (see Orton, 1926, p. 66). It may be remarked, however, that dumpy oysters increase in dimension on the lateral axis to a much greater degree than normally growing individuals.

7. On the Banks the catches of legal oysters ( $2 \frac{1}{2}$-inch ring) were in December, 1926, rather less than one-third of similar catches $\left(2 \frac{5}{8}\right.$-inch ring) in November, 1924. On the Edges and in the River the catches of legal oysters in December, 1926, were one-third to one-fifth of similar catches in November, 1924.

8. On the Banks in December, 1926, the average catch of small oysters is less than half of the average caught in November, 1924, while on the Edges and in the River beds the average catch of small oysters in Decem- 
ber, 1926, was rather more than half of the average caught per dredgehaul in November, 1924.

9. Thus in comparing catches in 1924 and in 1926, the legal oysters caught are seen to have diminished in the average haul from one-third to one-fifth, while the catches of small oysters have diminished to about a half. There is no doubt that the population of oysters has diminished in about the same ratio.

10. The recent input of oysters on the beds is represented by the brood FIG. 3.

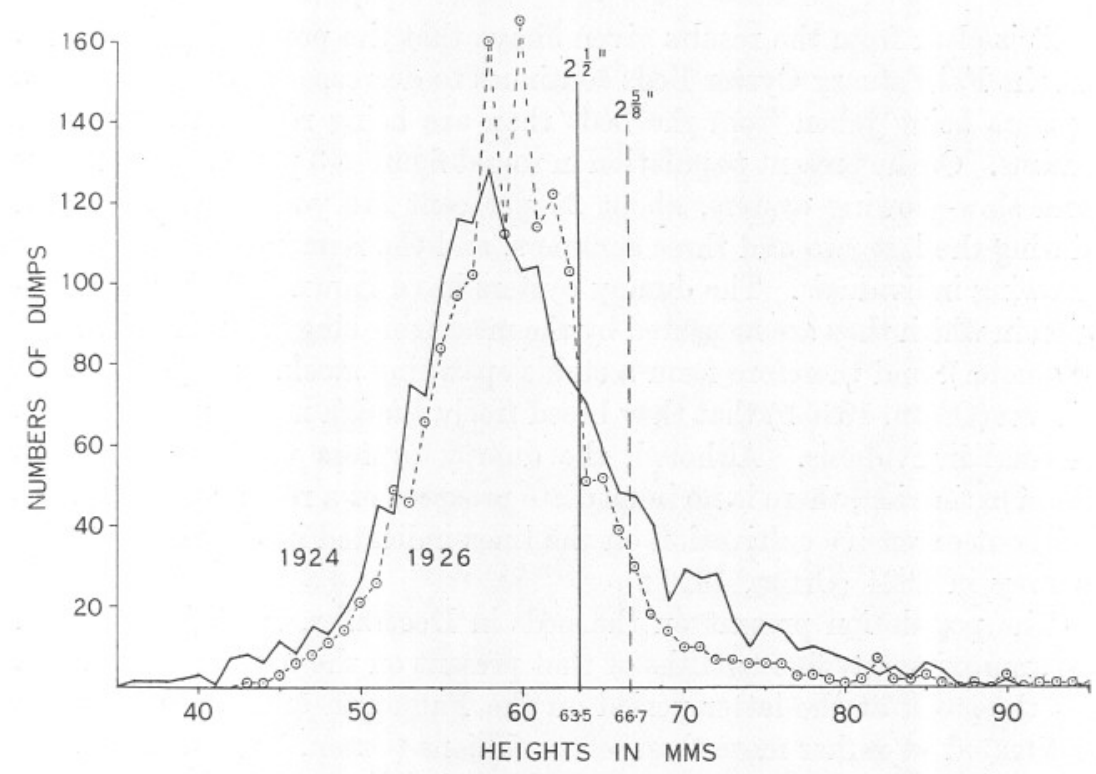

Fig. 3.-Graphs of the height (or depth)* of the shell in samples of dumpy and semidumpy oysters taken on the Truro beds, Upper Fal Estuary, respectively, in November, 1924, and December, 1926, indicating the extremely slow rate of increase in height (or depth) of the shell in this kind of oyster.

The graph of oysters taken, in November, 1924, is constructed from 1788 individuals taken from all parts of the beds, and that of the dumps taken in December, 1926, from 1,594 individuals also from all parts of the beds.

and spat, which constituted in December, 1926, about 18 per cent of the population. This recent input of oysters constitutes the addition made to the beds mainly in 1924,1925 , and part of 1926 .

11. The outtake of oysters from the beds is represented by the catches of large (legal) individuals, which amounted to 20 per cent of the total catches even in December, 1926. As the number of large oysters dredged

* The height or depth of the shell in this kind of oyster is in $99 \%$ of the cases the largest dimension of the shell; occasional shells are, however, longer than deep, and in such cases the longest dimension is included in the graph.

NEIV SERIES. - VOL. XIV. MAY, 1927. 
was greater at the beginning of the dredging season in 1926 the outtake of oysters at that time was greater than 20 per cent.

12. The present outtake of oysters from the Truro beds is thus greater than the input during the last few years, since it is shown that the average catch of small oysters (in spite of the addition of brood and spat to the stock) was smaller everywhere in 1926 than in 1924 . Therefore the beds are still being over-fished in the sense that a larger quantity of oysters is being taken from them than is being replaced by fresh stock.

\section{CONCLUSIONS.}

It is clear from the results given above that the population of oysters on the Fal Estuary Oyster Beds continues to decrease as a result of more oysters being taken from the beds than are being replaced by natural means. Of the present population in round figures 43 per cent are dumpy and slow-growing oysters, about 20 per cent are young oysters added during the last two and three summers, and the remainder are normally growing individuals. The dumpy oysters have grown little in the direction in which they are measured by the measuring ring $\left(2 \frac{5}{8}\right.$ inch in internal diameter), and therefore form a stable spawning stock, since it has been shown (Orton, $1926 \mathrm{~b}$ ) that they breed freely though not so prolifically as normal individuals. Although the dumpy oysters will save the beds from extinction, there is no immediate prospect of a recovery of the beds without extensive cultivation on the lines indicated in the report of the survey in 1924 (Orton, 1926 a).

The population present on the beds in December, 1926, is estimated at approximately five-twelfths of that present on the beds in April, 1925 . As the stock at the latter period on the Falmouth and Truro beds was estimated at rather more than seven millions (Orton, 1926 a, p. 74), the stock in December, 1926, in round figures, is estimated at three millions, since the Falmouth grounds were observed to be even less well stocked in December, 1926, than those under the administration of Truro.

Acknowledgment is gladly tendered to the Oyster Committee of the Truro Corporation for facilities for carrying out these observations.

\section{REFERENCES.}

Orton, J. H. 1926 a. Report on a Survey of the Fal Estuary Oyster Beds (November, 1924) with Notes on the Biology of the Oyster. Falmouth, 1926.

ORton, J. H. 1926 b. On Lunar Periodicity in Spawning of normally grown Falmouth Oysters (O. edulis) in 1925, with a Comparison of the Spawning Capacity of normally grown and dumpy Oysters. Journ. Mar. Biol. Assoc., N.S., Vol. XIV, No. 1, 1926. 